\title{
Inventing Narratives, Inventorying Natural Resources: Colonial Economic Exploitation in Conrad's Malay Fiction
}

\author{
Ari J. Adipurwawidjana \\ adipurwawidjana@unpad.ac.id \\ Department of Literature and Cultural Studies, Universitas Padjajaran, INDONESIA
}

\begin{abstract}
Literary narratives had accompanied global economic exploitation of natural resources since the rise of Britain as an imperial force in the late sixteenth century marked by Thomas Hariot's A Brief and True Report of the New Found Land of Virginia (1588), in which Hariot narrates, describes, and inventories natural and human resources in Virginia to invite economic interest and to justify colonization. The tradition of writing a descriptive overview of conquered lands was then furthered in the late eighteenth and early nineteenth centuries by Marsden's History of Sumatra (1783) and Raffles's History of Java (1817) as British colonial rule extended to the Malay Archipelago. However, towards the end of the nineteenth century, as economic and political rule inevitably gave way to complex sociocultural interaction, the fiction of Joseph Conrad set in the Archipelago, being novelistic in nature, provides a more dialogic portrayal of British colonial presence, particularly in Java and Borneo, which goes beyond mere justification for the exploitation of local resources. Following the cue from the work Edward Said in identifying textualization as a mode of colonial intellectual domination and Benita Parry in revealing the "ghostly" presence of empire in colonial fiction, I would like to argue that Conrad's Malay fiction both justifies and problematizes the relationship between British colonial enterprise and the natural as well as socio-cultural environment in the Archipelago.
\end{abstract}

Keywords: Joseph Conrad, colonial landscape, Malay fiction, subjunctive narrative, impressionism

\section{Introduction: Beginning a Narrative after an Inventory}

From the very beginning, Conrad's fiction has provided its readership with the ambivalence and complexities of the colonial condition. His so-called Malay fiction is of special significance to us, as the stories are set in those islands to which we belong. Now, as its readership has come to include $u s$, it has also presented $u s$ in this present time a space in which literary scholarship in archipelagic Southeast Asia may find a unique role in English literary scholarship. While during Conrad's time, we merely served as characters whose voice Conrad determines and often as characters we are mere metaphors for European concerns, now we are able to speak and write back and offer insight to the kind of world Conrad's fiction sees and tells about.
This is, again, apparent from the very beginning.

The words "Kaspar! Makan!" begin Conrad's Almayer's Folly (1895, p. 7). These two words represent the two aspects of the problem, which stem out of the fact that it is an imperative uttered in Malay. First, its serving as the opening of the first novel of a writer that was to be later recognized as a master stylist of modern, or at least modernist, fiction in English is oddly significant. If we consider the ramifications of what it means to be a beginning, as Said (1975) elaborates it, the imperative should endow her with authority, that is "the power of an individual to initiate, institute, establish-in short, to begin" (p. 83). However, this imperative is uttered by a Malay woman abducted out of her native cultural environment by a British merchant-king, Tom 
Lingard, who is glorified as the Rajah Laut, the King of the Seas. It is also an imperative directed towards her husband Kaspar Almayer. Thus, it is located in the beginning, but it does not begin the novel as such. It is just there. Almayer hears it, but does not attribute any meaning to it. He does not respond to it. In fact, he ignores it, and continues to ponder upon his alienated presence in the islands. These initial words do not have the force of an initiative because it is spoken in a foreign language by a character which is not granted authority in the novel's colonial context. Almayer's wife is a colonial subject and a displaced woman. In a colonial setting, the words of a Malay woman in her native tongue deserve no attention nor are they endowed with any kind of authoritative force. Consequently, Conrad's nineteenth-century readers may also ignore them as gibberish. Almayer, who dreams of returning home to the Netherlands, a home he has never been to, a home of which he is not a native, disregards the imperative because he is elsewhere. His eyes look toward "the Pantai," the estuary of the Berau river on the east coast of Borneo, either to find home in Holland or, more proximately, the promised wealth that Lingard, his absent father-in-law - the "gold he had failed to secure, gold the others had secured, [...] gold he meant to secure yet [...] for him and Nina," his Indo-Dutch daughter (p. 7-8).

However, the novel has become a part of the literary canon. Therefore, after two centuries, it has acquired readers, like myself, who is able to understand Malay, who are inclined to attribute meaning to those words. They are no longer foreign words. This is the second aspect of the problem. The inclusion of Malay words, commonly found in Conrad's fiction, offers a postcolonial reading of Conrad's canonical corpus, which enables us to recognize the "ghostly" presence of empire in colonial fiction, as Parry (2005) calls it. For the readers of Conrad's time, the meaningless Malay words are merely exploited as a kind of inventory of commodities absorbed into the colonial text much in the same way natural resources are extracted out of its local landscape for the benefit of a global economy.
Like Almayer, the anonymous white man in "The Lagoon," after listening to the story of his Malay friend, Arsat, continues on his journey. The white man seems to sympathize with Arsat's concerns about how he has forsaken his brother to live with the woman he loves despite the danger of her family's need to protect their honor. However, afterwards, he goes on his way "in pursuit of [his] desires, [...] which [they], men of the islands, cannot understand" (Conrad, 1898, p. 283), leaving Arsat "[standing] lonely in the searching sunshine, [... looking] beyond the great light of a cloudless day into the darkness of a world of illusions" (p. 297). The white man is also looking forward but towards something else, namely the natural wealth available for exploitation in the islands much in the same way Almayer looks out to the sea in search of Lingard's legendary wealth. For the duration of the narrative expounded by Arsat, who has exiled himself from his people and homeland to live with Diamelen, his love with whom he has run away, the white man seems sympathetic. Perhaps, it is because of the tragic sight of Diamelen's suffering a severe fever ending with her death. Or, it may also be due to his seeing Arsat as an Other, a metaphoric figure in the mirror against which he identifies himself, onto whom he projects his own anxieties. While Arsat in his exile is cut off entirely from his home, the white man is actually undertaking a journey already planned and mapped out as a part of what the anonymous narrator of "Heart of Darkness" calls "the interminable waterway" (Conrad, 1902, p. 51), which connects London and the natural resources and markets spread all over the world. What Almayer, the white man, and Marlow (in "Heart of Darkness," "Youth," and Lord Jim) see is an abundance of wealth already inventoried. Conrad's Malay Archipelago is that of the late nineteenth century. Earlier in the century, after his tenure as Lieutenant-Governor of the East Indies, Raffles published his History of Java (1817) in which he describes in detail the people, culture, and landscape as well as the natural resources. Raffles's elaboration of the environment on Java does not find its source purely from his direct observation and experience. He also, as he explicitly states in his book, made use of William Marsden's The History of Sumatra published in 1784. Both 
Marsden and Raffles are exponents of the English Orientalist tradition, the characteristics and operations of which Said comprehensively elaborates in his seminal Orientalism (1979). Their writing is an attempt to know the Orient as the object of Western knowledge. Such a knowledge is inherently political, for it means "rising above immediacy, beyond self, into the foreign and distant" enabling one to view his surroundings as an object of knowledge, which "is inherently vulnerable to scrutiny.... To have knowledge of such a thing is to dominate it, to have authority over it. And authority here means for 'us' to deny autonomy over it...since we know it and it exists, in a sense, as we know it" (Said, 1979, p. 32). This tradition of complementing political and economic domination with a scholarly one has begun since England started to build its global empire in the late sixteenth century as exemplified by Thomas Hariot's $A$ Brief and True Report of the New Found Land of Virginia first published in 1588. In this text, Hariot not only defends the project of establishing plantations and colonies in the New World against its opponents in England but also invites English subjects to participate in the endeavor. As it describes in detail the people, culture, and natural conditions of the so-called new found land, it performs the act and ability of having knowledge and therefore mastery over the landscape and its inhabitants.

Thus, Marsden's and Raffles's texts enact and document the act of knowing the Malay Archipelago. They contribute to the English collective knowledge. They do so to the extent that they significantly enriched the English lexicon. Elsewhere I have noted that the Oxford English Dictionary (OED) includes 191 entries identified as originating from Malay languages (Adipurwawidjana, 2014). A good portion of that number is traced to those words introduced to the English language by Marsden's and Raffles's texts. The incorporation of Malay-derived words into the English lexicon signifies, or at least suggests, that the Malay world including its peoples and landscapes, by the time Conrad and the characters of his fiction came into contact with it, had already become an integral part of English imagination. Thus, here I am suggesting that as Marlow in "Youth" and Lord
Jim, the anonymous white man as focalizer in "The Lagoon," and as narrator in "Karain" look at or towards the natural environment of the Archipelago, the landscape and its economic potentials are already inventoried and mapped out, for the characters as well as for Conrad's contemporary readers. The English man in the islands is not travelling blindly. Furthermore, Conrad's fiction has also contributed a significant number of words into the English lexical treasury, including the Malay words spoken by Malay characterswith as well as without gloss. In a way, the inclusion of Malay words into English vocabulary mirrors the kind of extraction of local resources to enrich the British economy.

Francis (2009) points out that the terrain and the commodities available in the Archipelago must have already been such common knowledge in Conrad's time that such detail mentioned in passing as Buitenzorg as Almayer's birthplace would have been understood as placing him at center of the colonial scholarly discourse as Buitenzorg had gained fame as the location of the Botanical Gardens. It could also be inferred, then, that Almayer is the product of the successful colonial attempt to manipulate and engineer local natural resources. A similar motif also occurs in Lord Jim where Stein, Jim's European mentor in residence, collects butterflies. And, it is this image of the re-appropriation of the natural environment that concludes the novel where the butterflies as the natural element of the islands serve as the metaphor for Jim the tragic hero himself.

\section{The Novelistic Ambivalent Stance towards the Colonial Project}

Although Conrad's fiction continues Marsden's and Raffles's project of enacting dominance over the islands through scholarly activity, its being fiction-and modernist at that-also opens up a space in which the Englishman's colonial experience is questioned. This space enables us to "move from a misconceived quest of the fictions' truths to consideration of their invention, reiteration or estrangement of colonialist perceptions and misconceptions," allowing us to see "these writings as culturally constrained 
and ideologically inflected fabrications that were overwhelmingly received in the imperial homeland as authentic renderings of oh distant geographical locations and social forms" (Parry, 2004, p. 107). Conrad's narrative technique does this by creating moments in the narration where the narrated event is stalled. At those moments, spaces are created that enables reflection and questioning. These instances, where the narrative is momentarily taken out of temporality, are created through two main narrative techniques. The first is the creation of such a textual space in which the flow what Genette (1980) calls the time of the story (histoire) is interrupted by a recourse to the focal character's mental processing the event into some meaningful significance. Brantlinger (1985) associates this narrative feature with the impressionistic presentation of aesthetic experience characteristic of the modernism of the early twentieth century. The other narrative technique that Conrad employs is what FitzPatrick calls the subjunctive narrative "in which significant information is not epistemologically secure" as the "result of the disruption between story and discourse" (2002, p. 245). Conrad, or rather his narrator, presents such a dubious presentation of events by using the actual subjunctive grammatical mode, as opposed as employing the indicative. This, then, serves as a means by which the narrative questions history as it is conventionally understood.

Thus, the call which Almayer supposedly hears as mentioned earlier from his wife, the Mem Putih (that is, literally, "the white mistress" despite her apparent Malay heritage, as Lingard had promised that "nobody will see the colour of [her] skin" [p. 16]), is an ineffective imperative. Within that same moment there exist two events, both out of place and out of time. From the perspective of Conrad's contemporary readers, Mrs. Almayer's call is an alien voice within a familiar language. From the point of view of Mrs. Almayer, Kaspar is a body only foreign because it cannot respond to the prevailing linguistic convention: when one is called to dinner, one comes home. But, of course, Almayer is thinking of another home. After several paragraphs, Almayer does re-cognize the call of "[t]he well-known shrill voice [which] startled Almayer from his dream of splendid future into the unpleasant reality of the present hour" (p. 7), that is, as if while he imagines the desired Europe-imagined to be past and never to be realized, the Malay language no longer holds meaning. He (through the narrator) does start to know Malay again, but then immediately disclaims it: "He had a hazy recollection of having been called some time during the evening by his wife. To his dinner probably" (p. 18). He, then, does decide that it is "[t]ime he went home, though;" but not because he is complying with the demand of the call to dinner, for "a man busy contemplating the wreckage of his past in the dawn of new hopes cannot be hungry whenever his rice is ready;" but because "it was getting late" (p. 18)-late in the century.

However, now, we are also there. I, as a reader who understands Malay, cannot be easily driven into doubt only because Kaspar pretends that his cognitive abilities fail as he looks out the estuary out to the sea which connects him to Amsterdam in the never-never land he imagines to be far from his exiled birth in Buitenzorg (present-day Bogor). Despite assurance from Dain Maroola, the character that claims to be the son the Balinese king preparing resistance against European rule, that his ability to carry out conversations in English with Kaspar Almayer will keep the locals from discovering the plot-theirs and, of course, Conrad's; I know as soon I begin reading the novel that he is called to dinner, not "[t]his dinner probably [my emphasis]." The meaning of "Kaspar! Makan!" is clear. It is only ambivalent for non-Malay, nonIndonesian speaking readers in Europe. Therefore, I know from the start that he is already in Europe.

The other way in which this beginning instance is an out-of-place event is that the narration leaves the present time already initiated by the call to dinner. The image provided to represent the shift to extratemporality reminds us of the Nellie in suspended time looking into the estuary of Thames towards London, imagining the Roman invasion of Britain as well as beginning Marlow's story of his penetration of the Congolese interior. Similarly, in the opening of Almayer's Folly, we find Almayer, "[taking] no 
further notice of the call. ...looking fixedly at the great river that flowed-indifferent and hurried-before his eyes[, when]... Almayer's thoughts were often busy with gold" (p. 7). In Lord Jim this suspended time is expressed in the subjunctive mode: "Perhaps it would be after dinner, on a verandah draped in motionless foliage and crowned with flowers" (Conrad, 1900, p. 33). Even when an emphatic affirmative statement is conveyed as testimony, it is subjunctive: "Oh yes. I attended the inquiry, he would say" (p. 33). (Emphases in both quotations are mine). This is the way the anonymous narrator introduces Marlow as the narrator of the following part of the story. In such a way, the fictional nature of the narrative becomes explicit. That is, Marlow's telling the story is presented as an event that may happen rather than one that actually does. It bluntly questions the historicity of the white man's colonial experience by presenting in the subjunctive mood which underlines its being an imagined occurrence based on the biases of Eurocentric subjectivity.

Conrad's somewhat metafictional habit of leaving the diegetic events at the level of story, to literally stall time by taking the narrative to the discursive level (récit) creates beneficent, benevolent ambiguity, which enables Conrad to escape the Manichean master-slave dichotomy. As I have elaborated before, from the very beginning, there is no simple colonizing white versus colonized brown opposition. Both the former Sulu princess and son of the colonial petty bureaucrat alternately take control of the diegetic situation as well as the narrative space in pursuit of treasure that a British global merchant, who has been "swallowed up by Europe," says exists. In fact, as the story progresses various other characters including Babalatchi the vizier, Nina the heir to both the decaying Lingard throne and possibly also to that of the king of Bali, and finally Abdulla the Arab merchant, occupant of the colonial liminal space, and making profit from it.

Racial identity for Almayer is not an advantage, though it may be an excuse for his inability to succeed in business. By the time Abdulla takes over (although he fails in getting Nina to marry his nephew), Almayer is indeed dead. Thus, if we buy into the proposition that to begin is to authorize the establishment of a reality, narratorial authoritative voice is never achieved in Almayer's Folly. Consequently, the novel never really begins just as Almayer's original plot never manifests. In fact, the novel ends with Abdulla uttering the traditional Islamic supplication in the initiation of any activity. It opens with an imperative, and it closes with an invocation. Yet, it never begins.

Ambiguity is achieved differently in Lord Jim, as it is in Heart of Darkness. When one cannot complete what he begins, he passes his narrative duty on to the next person all the way to Conrad himself. Both Jim and Almayer are severed from the metropolitan body. However, Jim has Marlow, who is "willing to remember him at length, in detail and audibly" (Conrad, 1900, p. 33) while Almayer has no one to vouch for his re-membership, as "Europe had swallowed up the Rajah Laut apparently, and Almayer looked vainly westward for a ray of light out of the gloom of his shattered hopes" (Conrad, 1898, p. 39). However, even with the well-maintained narrative relay from Jim to Marlow to the anonymous narrator, the liminal spaces between the transmission of the code allows for slippage, and the story momentarily is lost out of the author's control. Thus, the ambivalence and ambiguity in Conrad's fiction serve as a window in the narrative for us to see the "ghostly" presence of empire in the text.

\section{Affirming and Questioning Colonialism}

Chinua Achebe claims, in his famous critique of Heart of Darkness, that Conrad is a "purveyor of comforting myths" (2016, p. 16). Yet, as Cedric Watts (1983), a prominent Conrad scholar, contends, Heart of Darkness is in fact a critique of the colonial enterprise. Brantlinger, observing the statements made by the two eminent literary figures, suggests that the ambivalent and even contradictory critical responses to the work is due to the fact that "[t]he politics of Conrad's stor[ies] are complicated by [their] ambiguous style," one which "offers a powerful critique of at least certain manifestations of imperialism and racism, at the same time that it presents that critique in ways which can only be characterized as both imperialist and racist" (pp. 364-365). Brantlinger calls this style 
"impressionism," a term he borrows from Frederic Jameson (1981), ultimately originating from Ian Watt's analysis of Conrad's fictional corpus, referring to "the fragile skein of discourse which expresses-or disguises-[a] 'schizophrenic' contradiction as an apparently harmonious whole" (p. 365). This is the general illusionary feature of the rigorous structure of Conrad's fiction and the novel in general. What is clear here is that, whatever attitude Conrad's fiction may have toward imperialism, it clearly represents the problematic complexities of the imperialism when voiced through the perspective of its own agents, whose involvement with the enterprise is much too close and engaged that their view becomes myopic.

It also offers the portrayal of these imperial agents also as victims of the oppressive system, which they help to maintain, both deliberately on some level and unconsciously on another. Conrad's style is an important example of this problem because it does not merely tell a story about the ambiguous and ambivalent attitudes which agents of the colonial enterprise have but the text itself as well as its stylistic attributes is an imperial agent whose own narrative structure represents and contains the ambiguous and ambivalent-if not contradictory-elements of the "schizophrenic" mindset. Therefore, the novels by the virtue of its own structure and style provide a shaky moral attitude toward imperialism. It is so because it is not above imperialism, and therefore, cannot completely criticize even if it intended to do so. Lackey observes that "as scholars constantly observe, unstable knowledge and unreliable perception are persistent themes in Conrad's corpus," which results in "much confusion on the topic of Conrad's moral vision" (p. 20). Lackey echoes Brantlinger in his invocation of what Ian Watt "dubs 'subjective moral impressionism'” (p. 20). This so-called impressionism functions as a narrative strategy, regardless of its being consciously employed, which allows the narrative to center on individual perception, thus evading the portrayal a comprehensive picture of imperialism while allowing an inconsistent stance toward the atrocities which results from the economic exploitation of human beings.
The crux of the matter lies in the difficulty to pin down the narrative voice, which serves as the subject that operates the text as a process, which is also the voice that is in process and therefore fragmented. So, it may easily be concluded that the tendency of modern fiction, as exemplified by Conrad's style, to emphasize individual experience is complicit in the preservation of an oppressive economic system by maintaining a distance between the individual and his socio-economic environment. This over-emphasis on the inner workings of the human mind in a way helps to cause the schizophrenia which its impressionistic style represents. As the narrative perspective preoccupies itself on the internal microcosm, the voice collapses on itself leaving the external, material world to continue "business as usual."

In Almayer's Folly, Conrad's first novel, the novel as beginning, an egg, so to speak, breaks; and even in "Youth," "Karain," and Lord Jim all the king's men, (or, the Father's, or sailors' and merchants') could not put it together again. Just as Marlow attempts to remember Jimboth in the sense of mentally recalling and regaining membership, both novels seek to incorporate the scattered colonial experiences into the controlled structure of the novel genre, under the craft of Conrad the masterstylist. However, in the liminal spaces between the pieces there are gaps that present these ambiguities and ambivalences. The presence of these gaps allows the various contradictory statements made by Lingard, Almayer, Marlow, and other characters, who occupy the inner narrative framework-the histoire-of both novels to prevail in the unifying guise of Conrad's (and also the anonymous narrator's as well as Marlow's) well-crafted style.

However, it is this same gap that also allows Conrad, the anonymous narrator, Marlow, Jim, and even Almayer (or Kurtz) to have enough distance from their involvement in the colonial enterprise to have a glimpse at the obvious injustices that imperialism brings about. The presentation of the narrative instance in Heart of Darkness which frames the story of the series of events which constitute the diegetic world is clear. This structure, which makes the apparent distinction between actual events and events as they are told 
through a narrative, somewhat brings the narrative to the verge of completely exposing the nature of colonialism in all its aspects: economic, psychological, metaphysical, but seems to be hindered from completing the task just before it seems to be at the very threshold of doing so, similar to the way Marlow for some unexplainable reason refrains from telling truth about Kurtz to The Intended.

If we trust Jakobson's maxim that fiction works metonymically (Jakobson, 1987), and Jameson's that narratives are socially symbolic acts-from which he derives the notion that all Third-World literatures are national allegories, and from which we may make the analogy that all British literatures produced within the history of the British Empire are in one way or another imperial (Jameson, 1981); we may conclude that the novel by its definitive characteristics must suffer from aphasia and eventually breaks down under the weight of transnationality. Then, all indications of a unified structure are in fact illusionary. If we trust Jakobson's suggestion that both modes of figurative language, namely metonymy and metaphor are two types of aphasia, that is the inability to say what one means; we may conclude that, the birth of the global world economy causes consciousness to collapse since, as Spivak (1994) helpfully delineates, world shapes language and consciousness, and language structures both world and consciousness. Hence, the narrative disorder, however subtle it may be. In this sense, symbolism, such as the butterflies in Lord Jim or the distorted face of the dead man on the beach in Almayer's Folly, serves as a convenient substitute for external reality which expands too fast and too vast to be told coherently and cohesively within the confines of a story.

The debate between the critical blocs as represented by Achebe and Watts at least directs our attention to an important revelation: Marlow's story may not particularly even be about colonialism in Africa or the Indies but rather in England or Holland because the heart of darkness is ultimately attributed to London (and by extension also Amsterdam) rather than Kurtz's station or even the aberrative and irregular totally fictional Patusan, Sambir, or other colonial outposts. This may also have something to do with the minimal and onomastic use of proper names for the characters, for even characters (especially female ones) involved in central episodes and themes (Kurtz's native mistress, the Intended, in Heart of Darkness; Jewel, Tamb' Itam, Tengku Allang, Dain Waris in Lord Jim) are more symbols than persons, figures than individuals. However, the symbolical functions associated with female and Malay as Orientals differ from those linked to European male ones. The former in fact serve as attributes of male characters while the latter are expressed in terms of their role in the corporate enterprise. This presentation of characters as mere symbolical figures, according to Baldwin (2005), is indicative of the dehumanization of these characters. While the dehumanized presentation of non-white and female characters portrays them as sub-human but super-textual beings, that of the white, male characters convey them as mere functions (though powerful functionaries) of the colonial economic system. Thus,

the struggle is evident in a description which alternates between 'non-men' and 'men,' between "shadows," "shapes," and "men" [my emphases]. ... While many have noticed that Conrad's Africans [and women] are reduced to a less than human state, fewer have noticed the same imagery of hollowness connects these victims to those who dehumanize them, the sundry agents of the Company. (Baldwin 188)

That is to say, the oppressors are as dehumanized as the oppressed, despite the fact that they are more powerful and more at an advantage in imperial hegemony, which the narrative structure itself represents.

Then, the main issue, at least for the purposes of this paper, does not seem to be events of the colonial effort of corporations of global trade. It is not about what is being presented or represented, or how colonial or anti-colonial Conrad's fiction is. It is not even about, as Deleuze and Guattari (1987) state, "What it means?" or any other kind of what. It is rather about "How does it work?" Or, by the same token, how it does not and cannot work. 
The main issue is the limited capacity of narrative representation and human perception before the vastness of what human activity has achieved.

On at least three occasions in Heart of Darkness Conrad (through the anonymous narrator or Marlow) presents the problem of perception and interpretation of physical experience and material events. The first is when the anonymous narrator advises the reader on how to interpret Marlow's storymore of a warning that Marlow's story is not characteristic of the usual "yarns of seamen [which] have a direct simplicity, the whole meaning of which lies within the shell of a cracked nut" (Conrad, 1902, p. 55) -in that "the meaning of an episode was not inside like a kernel but outside, enveloping the tale which brought it out only as a glow brings out a haze, in the likeness of one of these misty halos that sometimes are made visible by the spectral illumination of moonshine" (Conrad, 1902, p. 55). This hints at a contextual reading of particular episodes as well as the story as a whole. This also implies that Marlow's tale is to be interpreted with consideration of the overall plot (more immediately this would probably mean the preceding and the following episodes), the context in which it was told, namely the circumstances on the Nellie, as well as the history of colonial conquest in general. Thus, the narrator is suggesting the reader to look for textual clues presumably provided throughout the tale. In a sense, it is a plea on the part of the text so that the interpretive act of the readers may discover the bread crumbs it leaves behind for it cannot by its own power escape the lure of conquest and imperialism.

The second occasion on which the problem of perception and interpretation arises is when Marlow notices "[s]ticks, little sticks, ... flying about--thick: they were whizzing before my nose, dropping below me, striking behind me against my pilot-house" (Conrad, 1902, p. 124). It seems that after only a while that Marlow realizes that the sticks are in fact "Arrows, by Jove!" Another similar example is when Marlow through his telescope the round knobs he sees set on poles are "not ornamental but symbolic" realizing that the knobs are in fact shrunken heads (Conrad,
1902, p. 142). This suggests that perhaps even the stylistic features of the whole novella may have a considerable contribution to its meaning.

Such moments of delayed perception also occur in Conrad's Malay fiction. In Lord Jim, the event in which Marlow first meets Jim, a misunderstanding is presented, in which Jim hears a derogatory remark made by some unidentified man about a dog as Marlow's sarcastic insult directed at Jim. Despite Marlow's insistence that he is not the one who has made the comment, let alone directing it at Jim as a verbal offense, Jim asserts that he does hear it. Marlow cannot deny the fact that he is there, and has been paying attention to Jim as the one being judged for the Patna incident. While Marlow does not make the comment which equates Jim to a "wretched cur" (Conrad, 1900, p. 74), he has, he admits, been somewhat making judgements about Jim.

In fact, in general the structure of Conrad's Malay fiction (and "Heart of Darkness") discussed here takes the form of a kind of reflection about European presence in the Archipelago. "Karain," even, is subtitles as "A Memory." The story is driven by the question: "What happened? Whatever could have happened?" (Deleuze \& Guattari, 1987, p. 192). The question places the narrative moment in a state of unknowing of events that have already passed and only knowing of the present moment as an undeniable state covered in doubt. Thus, "Karain" is a story of the anonymous white narrator trying to remember Karain as a figure deserving of his remembering him. "The Lagoon" is a story of the white man returning to revisit a past encounter, though he ultimately leaves to pursue economic advantage. "Youth" published in the same collection of stories as "Heart of Darkness," like "Heart of Darkness" is a story of men involved in colonial economic enterprises attempting to recount their past deeds in evaluation of the present situation. As Bignami (1987) suggests, the European characters of Conrad's Malay fiction seem to have the need to justify their presence in the islands.

All, like Lord Jim, are ultimately stories which judge with doubt the complicity in the 
morally questionable colonial project, as all of them also narrates figures dismembered from their respective communities and humanity in general seeking to redeem themselves through the act of remembering.

\section{Conclusion}

Donovan (1999), with reference to notions proposed by Ahmad (1994) remarks that Conrad corpus, particularly pertaining to his Malay fiction, is an example of what may be understood as "sites of contention between opposed 'discourses' of colonialism, and their ideas deemed self-contradictory or paradoxical" (p.33). The emphasis on the outof-time, subjunctive narrative instance and the delayed perception of the characters provide a space within the text, which does not only allow for the formulation of justifications for the imperial enterprise but also for selfcriticism as well as a space into which the reader may take part in further keep the gates of a colonial worldview, or dismantling them. More importantly, for us, Conrad's 21st. century readers from these islands, I insist, that the narrative spaces that Conrad's Malay fiction clears offer a site for our scholarly perspectives to the landscape that Conrad tells about, which is that we actually inhabit. Conrad's narrative technique plainly exposes that how the narratives are in fact inventions based Eurocentrically biased perspectives, and in so doing, dismantles the confident inventorying of the landscape of the Archipelago in the service of the imperial desire to exploit its resources. Thus, Conrad's Malay fiction has paved the way for us to remember ourselves of our own history and geography from our own eyes.

\section{References}

Achebe, C. (2016). An image of Africa. The Massachusetts Review 53 (1), 14-27.

Adipurwawidjana, A. J. (2014). Masuknya katakata Melayu ke dalam khazanah bahasa Inggris. In Amok dan Ancaman
Disintegrasi (25-30). Irfan Hidayatullah (Ed.) Bandung: Quacana.

Ahmad, A. (1992). In Theory: Classes, Nations, Literatures. London: Verso.

Baldwin, D. R. (2005). The horror and the human: the politics of dehumanization in Heart of Darkness and Primo Levi's Se questo è un uomo." Conradiana 37 (3), 185-204.

Bignami. J. (1987). Joseph Conrad, the Malay Archipelago, and the Decadent Hero. RES New Series 37.150 (1987): 199-210

Brantlinger, P. (1985). Heart of Darkness: Antiimperialism, racism, or impressionism? Criticism 27(4), 363-385.

Conrad, J. (1895) Almayer's Folly: A Story of an Eastern River. London: T. Fisher Unwin.

Conrad, J. (1898). Tales of Unrest. London: T. Fisher Unwin.

Conrad, J. (1900). Lord Jim: A Tale. Edinburgh: William Blackwood and Sons.

Conrad, J. (1902). Youth and Two Other Stories. Edinburgh: William Blackwood and Sons.

Deleuze, G. \& Guattari, F. (1988). A Thousand Plateaus: Capitalism and Schizophrenia, London: The Athlone Press.

Donovan, S. (1999). "Figures, facts, theories: Conrad and chartered company imperialism. The Conradian 24 (2), 31-60.

FitzPatrick, M. (2002). Indeterminate Ursula and "seeing how it must have looked," or, "the damned lemming" and subjunctive narrative in Pynchon, Faulkner, 0'Brien, and Morrison. Narrative 10 (3), 244-261

Francis, A. (2009). Recovering the ethics of economic botany in Conrad's Asian fiction. The Conradian 34 (2), 75-89.

Genette, G. (1980). Narrative Discourse: An Essay on Method. Ithaca, New York: Cornell University Press. 
Jakobson, R. (1987) Language in Literature. Cambridge Press: Belknap.

Jameson, F. (1981). The Political Consciousness: Narrative as a Socially Symbolic Act. Ithaca, N.Y.: Cornell University Press.

Lackey, M. (2005). The moral conditions for genocide in Joseph Conrad's Heart of Darkness. College Literature 32(1), 20-41.

Parry, B. (2004). Postcolonial Studies: A Materialist Critique. London: Routledge.

Raffles, T. S. (1830). The History of Java, Vols. 12. London: John Murray

Said, E. W. (1975). Beginnings: Intention and Method. New York: Basic Books.

Said, E. W. (1978). Orientalism. New York: Vintage.

Spivak, G. C. (1994). Feminism and critical theory. In Contemporary Literary Criticism: Literary and Cultural Studies (519-534). Robert Con Davis and Ronald Schleifer (Eds.). New York: Longman.

Watts, C. (1983). 'A bloody racist': about Achebe's view of Conrad. The Yearbook of English Studies 13, 196-209.

-—. (1996, October). "The Booby Trap." The New Republic, pp. 33-37.

-_. (2003, January). "Yeats and Form." Lannan Podcasts. Lannan Library. Retrieved from http://www.lannan.org/ events/helen-vendler

Vespers. (n.d.). In Online Etymology Dictionary. Retrieved March 3, 2019, from http://www.etymonline.com/index.php? term=vesper

Wild. (n.d.). In Merriam-Webster Collegiate Dictionary. Retrieved March 3, 2019, from https://www.merriam-webster. com/ dictionary/wild 